\title{
Adolescent suicide: an overview
}

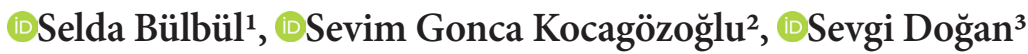 \\ ${ }^{1}$ Kırıkkale University Faculty of Medicine, Department of Social Pediatrics, Kırıkkale, Turkey \\ ${ }^{2}$ Kahramankazan Hamdi Eriș State Hospital, Clinic of Pediatrics, Ankara, Turkey \\ ${ }^{3}$ Etlik Zübeyde Hanım Training and Research Hospital, Ankara, Turkey
}

Cite this article as: Bülbül S, Kocagözoğlu SG, Doğan S. Adolescent suicide: an overview. J Health Sci Med 2021; 4(5): 752-757.

\begin{abstract}
Suicide is the second leading cause of death among 15-19 years old group globally. Recent years suicidal thoughts and attempts have increased in adolescents. While Turkey is among the countries with a low suicide rate, the last ten-year statistics show that suicide attempts have steadily increased especially among young people. The aim of this review is to determine the factors that cause suicide and to identify the necessary measures to prevent adolescent suicides.
\end{abstract}

Keywords: Adolescent, COVID-19, mental health, self-harm, suicide, prevention

\section{INTRODUCTION}

Suicide is the act of intentionally causing one's own death directly or indirectly by a positive or negative action. World Health Organisation (WHO) described the act of suicide as "self-harm with the awareness of one's purpose and with varying degrees of lethal purpose" in 1974 (1). The actions carried out with the intention of death but not resulting in death are defined as suicide attempt and the actions resulting in death are defined as completed suicide (2).

Suicidal thoughts and attempts have increased among adolescents in recent years (3). Moreover, suicide is the second leading cause of death among 15-19 years old group globally (4). While Turkey is one of the countries with a low suicide rate, the statistics show that suicide attempts have steadily increased especially among young people over the past 10 years (5). In the last 10 years, approximately 27,500 people in Turkey lost their life because of suicide and $34.3 \%$ of the people who attempted suicide were in 15-29-year-old group $(6,7)$. As a serious public health problem in this review, we aimed to determine the factors that cause suicide, to reveal the features and to identify the necessary measures to prevent adolescent suicides.

\section{Factors Affecting Suicidal Behavior}

There are many personal, social and environmental risk factors and also there are protective factors for adolescent suicides. Personal risk factors include family history of suicide or suicide attempts; history of adoption, male gender; parental mental disorders, lesbian, gay, bisexual, or questioning sexual orientation (LGBTQ); transgender identification, a history of physical or sexual abuse; pathologic Internet use, mental disorders, nonsuicidal self-injury (NSSI), and a previous suicide attempt. Social and environmental risk factors include impaired parentchild relationship, bullying, living outside of the home, social isolation, difficulties in school, neither working nor attending school, and presence of stressful life events, such as romantic difficulties or an argument with a parent. Protective factors could be listed as; religious involvement and connection between the adolescent and parents, school, and friends (8).

\section{Gender}

Several studies showed that the prevalence of suicide attempts is greater in girls than boys with a ratio varies between $3 / 1$ and 9/1 (8-10). Differences in hormonal and neurotransmitter levels between men and women could be the affecting factors. Impulsive behavioral disorders due to decrease in serotonin levels are more common in women (11). Moreover, hormonal changes during menstrual cycles increase the tendency to suicide in women. In some studies, FSH, LH, estrogen and progesterone were found to be lower than normal population in women who attempted suicide $(12,13)$.

Although suicide attempts are more common in women, completed suicide is 3 times more common in men (8). According to Turkish Statistical Institute 2015 data, 72.7\% of the completed suicide cases were men and $27.3 \%$ were women (7). During the act of suicide, males generally 
use more violent and lethal methods such as sharp instruments, firearms or hanging, while females mostly prefer methods such as taking drugs or jumping from high $(14,15)$. It is argued that males are more determined to die so they prefer much more lethal methods (15).

\section{Age and Age Range}

Suicidal behavior is rare before age of 12 but increases in prevalance through adolescence. The lower frequency of suicidal behavior before adolescence is explained by the inability of children to fully acquire the cognitive maturation that would enable them to plan and perform a suicidal attempt (16). The highest risk period in adolescence is the age of $14-16$ years $(3,17)$. In several studies conducted in different provinces of Turkey, the average age of suicide attempt was found to be 14.7 and 16.08 years $(9,17,18)$. As the middle adolescence is the complex period when most of the biological and psychological changes occur, social expectations can be perceived as pressure and adolescents can choose suicide as an escape route from their problems (19).

\section{Education Status}

According to Turkish Statistical Institute data, in the last ten years, primary school graduates constituted the highest rate of suicide cases (7). It is considered that, failure to attend school facilitates the suicidal tendency and individuals with low education level are more prone to suicide attempts $(2,9)$. In accordance with this hypothesis, Kesebir et al. (20) revealed that individuals with low education level had less suicide attempt but preferred more lethal suicide methods comparing to those with higher education level.

\section{Personal and/or Parental Mental Disorders}

While the individual tries to cope with stressful life events during adolescence, mental diorders such as depression, affective and anxiety disorders may occur (16). The rate of depression in the middle and late adolescence period is between $4-20 \%$ and there is a strong relationship between depression and suicide attempt (21). It was shown that, mental disorders are the leading causes of suicide and an individual with major depression has a 20-30 times greater risk of suicide than the general population (20-22).

Considering the underlying causes of depression in adolescence, the most prominent causes are family problems, parental separation, presence of a psychiatric disorder in a family member, school failure, and chronic illness $(9,10)$. Studies on adolescents who attempted suicide showed that anger and impulsivity were more common than the healthy adolescents (9). Yalaki et al. (10) showed that $86.8 \%$ of the adolescents who had a previous diagnosis of psychiatric disorder, were showing depressive symptoms during the period when they attempted suicide. Moreover, depressive symptoms were also observed in the mothers of $73.7 \%$ of adolescents diagnosed with psychiatric disorders. These results revealed that depressive symptoms of the adolescent and/ or a family member and problems within the family would affect each other. It was claimed that approximately 2-3\% of adolescents received medical care after suicide attempt, less than $50 \%$ had psychotherapy after intervention in emergency services, and most of those who started treatment did not complete their treatment (23). Ekici et al. (24) showed that the presence of physical illness and insufficient dose of psychiatric treatment are two important risk factors for completed suicide. Another study, reported that $15 \%-21 \%$ of the cases had stated that they would attempt suicide again (25). Therefore, regular psychiatric follow-ups of these individuals are required. For the ones who cannot be reached for follow-ups should be contacted and informed about the seriousness of the situation and these individuals should have psychiatric treatment.

\section{Family Effects}

Parental separation, presence of suicidal attempts in family members, or family history of psychiatric disorder were shown as important risk factors for suicide $(26,27)$. Many studies showed that, the parents of adolescents with suicidal behavior had lower education levels and the rate of psychiatric disorder presence in a family member was higher compared to normal population $(10,28)$

\section{History of Physical or Sexual Abuse}

It has been reported that sexual or physical abuse during childhood and adolescence increases the risk of suicide throughout life $(8,29,30)$. In a large sampled survey study examining the relationship between abuse and selfharming behavior in high school students in Turkey, it was determined that $34.8 \%$ of adolescents had been exposed to trauma, $10.7 \%$ had been sexually abused and $25.2 \%$ of the cases subjected to sexual abuse had a history of suicide attempt (31). The brutality of sexual harassment can also have an effect on suicidal behavior. Evans et al. (32) revealed that, the rate of suicide attempt was 3.3\% in cases with non-contact sexual abuse history, $8.3 \%$ in involving touching, and $15.2 \%$ in abuse involving sexual intercourse.

\section{School Related Factors}

School failure emerges as an important reason for both suicide attempt and adolescent depression (10). Eskin et al. (33) found that $25.7 \%$ of 966 high school students had thought of suicide at least once. In another study, it was revealed that the source of psychological problems in high school students who attempted suicide was the anxiety of failing the university exam (16). Ozfirat et al. (34) revealed that $64.2 \%$ of the senior high school students with school failure and $36.8 \%$ of successful students showed depressive symptoms. 


\section{Internet Use}

Copycat suicide is an imitative suicidal behaviour that occurs after exposure to another suicide. Increases in internet news and social network services in recent years have provided a highly connected matrix whereby provocative news articles, including reports of celebrity suicide, can travel rapidly and widely (35). It was reported that exposure to suicidal news, describing suicidal methods or relevant contents through television or social media, affect adolescents more than adults, and also causes cluster-style suicidal behavior around them $(8,36)$. Daily use of Internet and video games exceeding 5 hours was strongly associated with higher levels of depression and suicidality (ideation and attempts) in adolescents and suicide-related Internet searches were found to be associated with completed suicides among young adults $(8,37)$.

\section{Nonsuicidal Self-Injury (NSSI)}

Nonsuicidal self-injury (NSSI) is defined as repeating, self-harming behaviours which do not include intention to die, and risk of death is deliberately low. Nonetheless, NSSI is a risk factor for suicide attempts and suicidal ideation. In the first 6 months after NSSI, the risk of suicide was found to be very high, and was mentioned that the risk continued later (38).

\section{Lesbian, Gay, Bisexual, Transgender, and Questioning (LGBTQ) Adolescents}

Lesbian, gay, bisexual, transgender, and questioning (LGBTQ) adolescents experience higher rates of substance use, risky sexual behaviors (HIV, sexually transmitted infections, unintended pregnancies) and suicidal attempts. Stigma and minority stress processes are the major theorized causes of this negative health outcomes experienced by LGBTQ populations. These stressors activate a physiological stress response, which can affect the mental and physical health of stigmatized populations, and lead to suicidal attempts (39). Risk factors and causes of suicide in LGBTQ population can differ according to age or type of sexual orientation. In a study about LGBTQ suicides, it was found that 12- to 17 -year-olds had a 3.6 times more suicidal attempts than 18- to 29-year-olds and cases of gay males, bisexual males and bisexual females were particularly likely to include family/peer rejection and bullying as contributing circumstances, while lesbians' cases more often mentioned romantic breakups (40)

\section{Suicide Ideation and Attempts During The Covid 19 Pandemic}

In many reports, elevated rates of mental health concerns have been identified during the COVID-19 pandemic. Due to restrictions and lock downs, greater levels of negative COVID-19 experiences were associated with increased depressive symptoms and anxiety among adolescents (41). Results from a emergency service study indicated a significantly higher rate of suicide ideation in March and July 2020 and higher rates of suicide attempts in February, March, April, and July 2020 as compared with the same months in 2019 among youth aged 11 to 21 (42).

\section{FEATURES OF SUICIDE}

\section{Time of Suicide}

There are many studies investigating on the effects of climate conditions on suicide and these studies revealed that the time of suicide varied according to the region, season or the province of the study (43-48). The studies conducted in Turkey among adolescents showed that suicide attempts were increasing in summer, during the closing period of schools, where the peak was seen in spring or winter months (45-47). It is thought that, decrease in school success among adolescents, especially during school closure periods, constitutes a risk factor for suicide attempts $(47,48)$. In addition, stress of the exams and as warming of the weather, romantic breakups can be shown as the reasons for an increase in suicide attempts in spring and summer months (49).

\section{Hour and Location of Suicide}

The suicide hour varies according to the age, determination of the individual and the choice of method (48). It has been stated that, majority of the adolescents attempts suicide between 18.00-24.00 hours $(48,49)$. The main purpose of suicidal attempts without the idea of death is to attract the attention of parents or friends, to show problems that cannot be solved; briefly to call for help. For this reason, evening hours are preferred by adolescents more frequently when the family members can interfere with them (48). In contrast, Taktak et al. (50) showed that the completed suicide attempts usually (70.2\%) occured during the day time. It was also suggested that adolescents mostly choose the evening hours when they are not active and alone, and the most preferred places for suicide attempts are their homes $(50,51)$.

\section{Methods of Suicide}

The determination for death affects the chosen method. Adolescents generally attempt suicide due to their impulsiveness (47). By suicide attempt they express themselves to seek help or take attention rather than desire to die $(18,47)$. It was shown that, the most common method in suicide attempts in adolescence is drug intake $(52,53)$. However, in completed suicides, the most common methods have been reported as suffocation, firearm, poisoning and high jump (8). The most preferred drugs are the frequently available or can be easily obtained drugs at home such as analgesics/anti-inflamatory drugs, antidepressants, antipsychotics, antibiotics, cardiac and stomach drugs $(10,52,54)$. 


\section{Preventing Adolescent Suicides}

Along with all information, unfortunately, suicide is not an accurately predictable situation but health care professionals can only determine who is at higher risk. Intent is a major key in the determination of risk. Adolescents at high risk are those with a plan or recent suicide attempt with a high probability of lethality; stated current intent to die, recent suicidal ideation or agitation, impulsivity or severe hopelessness; or profoundly dysphoric mood associated with bipolar disorder, major depression, psychosis, or a substance use disorder (8). Therefore, pediatricians should screen adolescents for suicidal thoughts, mood disorders, and alcohol/drug abuse in their visits. Suicidal ideation may be assessed by directly asking questions or screening via self-reports. Self-administered scales can be useful because adolescents may disclose information about suicidality on self-reports which they deny in conversation (8).

It is always necessary to understand nonsuicidal selfinjury (NSSI) and suicide attempts as the adolescent has a dilemma and they should be referred for help. If the adolescent has ever had at least one NSSI behaviour, she/he should be consulted to adolescent psychiatry and follow-up visits should be conducted in collaboration. The most important point in treatment is to prevent external factors that push the patient to NSSI and suicidal attempt and to increase the adolescent's ability to cope with stress, solve problems, control their emotions and impulsivity. If there is a concomitant psychiatric illness, it should be treated by medication and/or psychotherapy (38). Among the antidepressants, fluoxetine is formally approved by the Food and Drug Administration (FDA) for treating depression in pediatric patients and sertraline, fluvoxamine, and clomipramine are approved for treating obsessivecompulsive disorder (OCD) in children and youth (55). Lithium, with antimanic and antidepressant effects, is the gold standard mood-stabilising agent for the treatment of adolescents with bipolar disorders, and has anti-suicide effects (56).

The FDA recommends that a child receiving anti depressants should visit the prescribing physician once a week for the first four weeks of treatment; biweekly for the second month of treatment; and at the end of the $12^{\text {th }}$ week on medication (55). Along with the treatment, adolescents should be supported to participate in volunteer services to assist people in need of help, participate in social, creative and sports activities and/ or artistic courses with peers. All this will allow the adolescent to gain self-confidence and positive selfperception and will also give the adolescent the ability to cope with external difficulties $(8,38)$.
There are many suicide prevention efforts all around the World that focused on school education programs, crisis center hotlines, media guidelines (suicide prevention strategies that involve educating media professionals about the prevalence of copycat suicides among adolescents, in an effort to minimize the impact of news stories reporting suicide) and efforts to limit firearm access (57). Morken et al. (58) suggest that school-based interventions prevent suicidal ideation and attempts in the short term, but prevent suicide attempts in the long term. Considering that adolescents are in the high-risk group of suicide attempts, it is very important to generalize school health services and adolescent health units in preventing these attempts so WHO has mostly focuses on school education programs to prevent suicide (59).

It should be known that before suicide attempt, many cases convey their suicidal thoughts directly or indirectly to their friends and families. Informing students about signs and symptoms associated with suicide would help them to notice the current symptoms and could explain to their friends. It is believed that the inclusion of training programs with presentations, video screenings, activities and discussions on behavioral disorders, violence, abuse and suicide in the National Education Curriculum of the high school students, could be protective (2). World Health Organisation (WHO) focuses on school-base interventions to prevent adolescent suicide attempts. They recommend: Strengthening the mental health of schoolteachers and other school staff, strengthening students' self-esteem, promoting emotional expression, preventing bullying and violence at school, providing information about care services, communication and improving school staff's skills to prevent suicide among adolescents (59).

In Turkey, a pilot programme titled "Psychosocial Support and Intervention of Crisis Program for Suicide Attempts in Emergency Service" was initiated by the Ministry of Health Department of Mental Health and has been implemented in 32 provinces in 2004. The aim of this program was to record suicide attempts in emergency services and to create a database. Moreover, in suicidal attempt cases, the programme provides the adolescents and their families psychosocial support. It was planned to create a surviallance by filling out the "suicide attempt feedback form" for the cases recorded as suicidal attempt. After initial evaluation and intervention at the emergency service, they are referred to the psychosocial support unit, then after, cases deemed necessary were consulted with psychiatry. Relatives of the patients were included in this process when it is necessary (60). 


\section{CONCLUSION}

Adolescent suicide is an important public health problem. The causes include psychological, environmental and social factors, and mental disorder is theleading risk factor for suicide. Suicide risk factors vary with age, gender, family dynamics and stressful life events. Although there are some possible warning signs, it is difficult to accurately predict which persons with these risk factors will ultimately commit suicide. As we are pediatricians who follow adolescents in our clinics, we should be aware of risk factors, regularly screen adolescents and do collaborative safety planning for suicidal patients.

\section{ETHICAL DECLARATIONS}

Referee Evaluation Process: Externally peer-reviewed.

Conflict of Interest Statement: The authors have no conflicts of interest to declare.

Financial Disclosure: The authors declared that this study has received no financial support.

Author Contributions: All of the authors declare that they have all participated in the design, execution, and analysis of the paper, and that they have approved the final version.

\section{REFERENCES}

1. Weis M: Suicide. In: S. Arieti (ed). A Handbook of Psychiatry. Newyork: Basic Books Inc; 1974: 743-65.

2. Bilginer Ç, Çöp E, Göker Z, Hekim Ö, Sekmen E, Üneri Ö. İlaç içerek intihar girişiminde bulunan gençler ve koruyucu-önleyici hizmetlere genel bakış. Dusunen Adam J Psychiatry Neurol Sci 2017; 30: 243-50

3. Özgüven Devrimci H, Sayıl I. Suicide attempts in Turkey: Results of the WHO-EURO multicentre study on suicidal behaviour. Can J Psychiatry 2003;48: 324-9

4. CDC, National Center for Health Statistics, Adeolescent Health, https://www.cdc.gov/nchs/fastats/adolescent-health.htm (Access March 20, 2021)

5. Ayas S, İsssizlik ve eğitim seviyesinin intihar üzerindeki etkisi: TÜİK verileri üzerine ampirik bir çalışma. Yönetim Bilimleri Derg / J Administrative Sci 2016; 14: 101-19.

6. Bilici M, Bekaroglu M, Hocaoglu C et al. Incidence of completed and attempted suicide in Trabzon, Turkey. Crisis 2002; 23: 3-10.

7. Türkiye İstatistik Kurumu (TUIK), Türkiye İntihar İstatistikleri, 2015, http://www.tuik.gov.tr (Access August 8, 2017)

8. Shain B. Committee on adolescence, suicide and suicide attempts in adolescents. Pediatrics 2016; 138: e20161420

9. Akin E, Berkem M. İntihar girişiminde bulunan ergenlerde öfke ve dürtüsellik. Marmara Med J 2012; 25:148-52

10. Yalaki Z, Çakır İ, Taşar M, Yalçın N, Bilge Y. Anne ve ergenlerdeki depresif belirtilerin ergen intiharları ile ilişkisi. Dicle Med J 2012; 39: 350-8.

11. Nock MK, Borges G, Bromet EJ, et al. Suicide and suicidal behavior. Epidemiol Rev 2008; 30: 133-54.

12. Kim B, Kang ES, Fava M, et al. Follicle-stimulating hormone (FSH), current suicidal ideation and attempt in female patients with major depressive disorder. Psychiatry Res 2013; 210: 951-6.
13. Baca-Garcia E, Diaz-Sastre C, Ceverino A, et al. Suicide attempts among women during low estradiol/low progesterone states. J Psychiatr Res 2010; 44: 209-14.

14. Carroll-Ghosh T, Victor BS, Bourgeois JA, Suicide. In: Hales RE, Yudofsky SC (eds) Textbook of Clinical Psychiatry, 4th edition. Washington DC: The American Psychiatric Publishing 2003: 1457-83.

15.Eskin M, Albuharian F, Rezaeian M, et al. Suicidal thoughts, attempts and motives among university students in 12 muslimmajority countries. Psychiatry Q 2019: 90; 229-48.

16. Hawton K, Saunders KE, O'Connor RC. Self-harm and suicide in adolescents. Lancet 2012; 379: 2373-82.

17. Yektaş Ç, Bildik T, Özbaran NB, Köse S, Erermiş S. Depresif kiz ergenlerde intihar davranişinin klinik özellikleri. Çocuk ve Gençlik Ruh Sağlığı Derg 2014; 21: 33-44.

18. Çelik G, Yıldırım V, Metin Ö. Özkıyım girişimi olan ergenlerde ruhsal bozukluklar, benlik ve aile işlevselliği. Anatolian J Psychiatry 2011; 12: 280-6.

19.Sayar K, Öztürk M, Acar B. Aşırı dozda ilaç alımıyla intihar girişiminde bulunan ergenlerde psikolojik etkenler. Klinik Psikofarmokoloji Bülteni 2000; 10: 133-8.

20. Kesebir S, Gülpek D, Noyan MA. Özkıyım girişimlerinin doğası, Anadolu Psikiyatri Derg 2002; 3: 88-94.

21.Eskin M. Lise öğrencisi ergenlerde depresyonun yaygınlığ1 ve ilişkili olduğu etmenler. Türk Psikiyatri Derg 2008; 19: 382-9.

22. Aydemir Ç, Vedin TH, Göka E. Major depresyon ve özkıyımda kognitif ve emosyonel faktörler. Türk Psikiyatri Derg 2002; 13: 33-9.

23. Köse A, Eraybar S, Köksal Ö, Patients over the age of 15 years admitted for attempted suicide to the emergency department and the psychosocial support unit. JAEM 2012; 11: 193-6.

24.Ekici G, Savaş HA, Çıtak S. Tamamlanmış intiharlarda iki önemli risk etmeni: fiziksel hastalığın varlığı ve yetersiz dozda psikiyatrik tedavi, Klinik Psikofarmakoloji Bülteni, 2001; 11: 168-9.

25.Hvid M, Vangborg K, Sorensen HJ et al. Preventing repetition of attempted suicide-II. The Amager Project, a randomized controlled trial. Nord J Psychiatry 2010; 65: 292-8.

26. Mittendorfer-Rutz E, Rasmussen F, Lange T. A life-course study on effects of parental markers of morbidity and mortality on offspring's suicide attempt. PLoS ONE 2012; 7: e51585.

27. Akbas S, Boke O, Karabekiroğlu K, et al. Hastane başvurusu intihar girişimi ile olan ve olmayan depresif çocuk ve ergenlerin ayırt edici özellikleri. Türkiye'de Psikiyatri 2008;10:2

28. Güleç G, Aksaray G. İntihar girişiminde bulunan gençlerin sosyodemografik sosyokültürel ve aile özelliklerinin araştırılması. Yeni Sempozyum 2006; 44:3

29. Bebbington PE, Cooper C, Minot S, et al. Suicide attempts, gender, and sexual abuse: data from the 2000 British Psychiatric Morbidity Survey. Am J Psychiatry 2009; 166: 1135-40.

30. Wong WH, Kuo WH, Sobolewski C, Bhatia I, Ip P. The association between child abuse and attempted suicide. Crisis 2020; 41:196204.

31.Zoroğlu SS, Tüzün Ü, Şar V, Öztürk M, Kora ME, Alyanak B. Çocukluk dönemi istismar ve ihmalinin olası sonuçları. Anadolu Psikiyatri Derg 2001; 2: 69-78.

32.Evans E, Hawton K, Rodham K. Suicidal phenomena and abuse in adolescents: a review of epidemiological studies. Child Abuse \& Negl 2005; 29: 45-58.

33. Eskin M. Gender and cultural differences in the 12- month prevalence of suicidal thoughts and attempts in Swedish and Turkish adolescents. Journal of Gender, Culture and Health 1999; 4: 187-200.

34. Özfirat Ö, Pehlivan E, Özdemir F. Malatya il merkezindeki lise son sınıf öğrencilerinde depresyon prevalansı ve ilişkili faktörler. İnönü Üniversitesi Tip Fakültesi Derg 2009; 16: 247-55. 
35. Yi H, Hwang J, Bae HJ, Kim N. Age and sex subgroups vulnerable to copycat suicide: evaluation of nationwide data in South Korea. Sci Rep 2019; 9: 17253.

36. Copeland WE. Editorial: One Reason Why Not. J Am Acad Child Adolesc Psychiatry 2020; 59: 216-8.

37. Messias E, Castro J, Saini A, Usman M, Peeples D. Sadness, suicide, and their association with video game and internet overuse among teens: results from the youth risk behavior survey 2007 and 2009. Suicide Life Threat Behav 2011; 41: 307-15

38. Birinci basamak sağlık çalışanları için ergen sağlığına ve sorunlarına yaklaşım cep kitabı, 2017; 42-3, https://kirklareliism. saglik.gov.tr/Eklenti/115480/0/birinci-basamak-saglikcalisanlari-icin-ergen-sagligina-ve-sorunlarina-yaklasim-cepkitappdf.pdf (Access March 8, 2021)

39. Johns MM, Poteat VP, Horn SS, Kosciw J. Strengthening our schools to promote resilience and health among LGBTQ youth: emerging evidence and research priorities from The State of LGBTQ Youth Health and Wellbeing Symposium. LGBT Health 2019; 6: 146-55.

40. Ream, GL. An investigation of the LGBTQ+ youth suicide disparity using national violent death reporting system narrative data. J Adolescent Health 2020; 66: 470-7.

41. Mamun MA, Sakib N, Gozal D, Bhuiyan AI, Hossain S, BodrudDoza $\mathrm{M}$ et al. The COVID-19 pandemic and serious psychological consequences in Bangladesh: A population-based nationwide study. J Affect Disord. 2021; 279: 462-72.

42. Hill RM, Rufino K, Kurian S, Saxena J, Saxena K, Laurel Williams. Pediatrics. 2021;147:e2020029280.

43. Christodoulou C, Efstathiou V, Bouras G, Korkoliakou P, Lykouras L. Seasonal variation of suicide. Encephalos 2012; 49:73-9.

44. Çam B, Karlıdere T, Aytekin S. İntihar girişimi, sosyodemografik özellikler ve mevsimsellik. Klinik Psikofarmakoloji Bülteni 2012; 22: 158 .

45. Şevik AE, Özcan H, Uysal E. İntihar girişimlerinin incelenmesi: Risk faktörleri ve takip. Klinik Psikiyatri Derg 2012; 15: 218-25.

46. Günderci A, Karatay G, Tunceli' de 2005-2015 y1lları arasında gerçekleşen intiharlara ilişkin epidemiyolojik bir inceleme, Klinik Psikiyatri 2017; 20: 121-8.

47.Görücü A, Eraslan R, Göker Z. Dürtüsel Nitelikteki Özkıyım Girişiminde Mevsimin Etkisi: Tanımlayıcı Bir Çalışma. Türkiye Çocuk Hastalıkları Derg 2020; 1-6.

48. Johnson GR, Krug G, Potter LB, Suicide among adolescents and young adults: A cross-national comparison of 34 countries. Suicide and Life-Threatening Behavior 2000; 30: 74-82.

49.Söğüt Ö, Sayhan M, Gökdemir M. Türkiye’nin Güneydoğusunda, Şanlıurfa ve Çevresinde Özkıyım Girişimlerinin Değerlendirilmesi, JAEM 2011; 8-13.

50. Taktak S, Üzün İ, Balcıoğlu İ. İstanbul'da tamamlanmış intihar olgularının psikolojik otopsisi, Anadolu Psikiyatri Derg 2012; 13: 117-24.

51. Yalaki Z, Taşar MA, Yalçın N, Dallar Y. Çocukluk ve gençlik dönemindeki özkıyım girişimlerinin değerlendirilmesi, Ege Tıp Derg 2011; 50: 125-8.

52. Miniksar Ö, Yıldız Miniksar D. Yoğun bakım ünitesinde takip edilen ergen ilaç intoksikasyonların retrospektif değerlendirilmesi. J Health Sci Med 2020; 3: 203-8.

53. Eaton D.K. Youth Risk Behavior Surveillance -United States, 2011. Morbidity and Mortality Weekly Report 2012; 61.

54. Güloğlu C, Gökhan Ş, Üstündağ M, Orak M. Acil servise başvuran olguların kullandıkları yöntemler ve demografik verilerinin mortalite ile ilişkisi. Türkiye Acil Tıp Derg 2009; 9: 109-14.

55.American Psychiatric Association and American Academy of Child and Adolescent Psychiatry. The use of medication in treating childhood and adolescent depression: information for physicians. www.parentsmedguide.org/physiciansmedguide.pdf. (Access April 2, 2021)
56. McIntyre RS, Berk M, Brietzke E, et al. Bipolar disorders. Lancet 2020; 396: 1841-56

57. Teen Suicide is Preventable, American Psychological Association https://www.apa.org/research/action/suicide July,10,2021)

58. Morken IS, Dahlgren A, Lunde F, Toven S. The effects of interventions preventing self-harm and suicide in children and adolescents: an overview os systematic review. F1000Research 2020; 8: 890 .

59. WHO Preventing suicide A Resource for teachers and other school staff. https://www.who.int (Access: July 10, 2021)

60. Acil Serviste İntihar Girişimlerine Psikososyal Destek ve Krize Müdahale Programı, Sağlık Bakanlığı, Temel Sağlık Hizmetleri Genel Müdürlüğü, Ruh Sağlığı Daire Başkanlığı,2004 http:// www.istanbulsaglik.gov.tr/w/sb/halksag/belge/mevzuat/acilde_ intihar_girisim_psiko_destek_kriz_muda_prg.pdf (Access October 10, 2020) 